\title{
ウシ・グレリン受容体遺伝子の塩基多型、分子進化および
} その塩基多型と産肉形質との関連性

\author{
小松正憲 $1^{*}$ 、藤森祐紀 $2^{\#}$ 、伊藤智仁 ${ }^{3}$ 、佐藤洋一 4 、垪和靖俊 2 、 \\ 西尾元秀 1 、岡村裕昭 5 、佐々木 修 1 、高橋秀彰 1 、佐藤正寛 1
1 独立行政法人農業・食品産業技術総合研究機構・畜産草地研究所
下 305-0901つくば市池の台 2
2 茨城県畜産センター・肉用牛研究所
3 家畜改良事業団・家畜改良技術研究所
4 岩手県農業研究センター・畜産研究所
5 独立行政法人農業生物資源研究所
\# 現在、長野県畜産研究所

\section{Nucleotide polymorphisms and molecular evolution of the bovine growth hormone secretagogue receptor 1a (GHS-R1a) gene and its genetic association with carcass traits in Japanese Black cattle}

\author{
Masanori KOMATSU ${ }^{1 *}$, Yuki FUJIMORI ${ }^{2 *}$, Tomohito ITOH ${ }^{3}$, Yoichi SATO ${ }^{4}$, \\ Yasutoshi HAGA $^{2}$,Motohide NISHIO ${ }^{1}$, Hiroaki OKAMURA ${ }^{5}$, Osamu SASAKI ${ }^{1}$, \\ Hideaki TAKAHASHI ${ }^{1}$, Masahiro SATOH ${ }^{1}$ \\ ${ }^{1}$ National Institute of Livestock and Grassland Science (NILGS), Tsukuba, Japan. \\ ${ }^{2}$ Ibaraki Prefecture Livestock Research Centre, Hitachi-Ohmiya, Japan. \\ ${ }^{3}$ Maebashi Institute of Animal Science, Livestock Improvement Association of Japan, Inc. (LIAJ) Maebashi, Japan. \\ ${ }^{4}$ Iwate Prefecture Livestock Research Centre, Takizawa, Japan. \\ ${ }^{5}$ National Institute of Agrobiological Sciences (NIAS), Tsukuba, Japan. \\ \# Present address: Nagano Prefecture Livestock Research Centre, Shiojiri, Japan.
}

\section{要 約}

グレリン受容体は主に視床下部・弓状核および下垂体等で発現し、成長ホルモン（GH）分泌や摂食光進作用を 持つ「グレリン」の機能を発揮させる重要な受容体である。我々は、ウシ・グレリン受容体遺伝子全長（約 6.5 キ 口塩基対）の塩基配列をウシ 13 品種で決定し、塩基多型の全容を明らかにした。1,285 頭の黒毛和種後代検定牛 集団を用い、本遺伝子の塩基多型と増体形質との関連性を検討したところ、5'UTR マイクロサテライト（(TG $\left.)_{\mathrm{n}}\right)$ と nt-7（C＞A）座位に有意関連性を認めた。この関連性を説明する仮説（“translational hypothesis”）を提案した。

\section{1.はじめに}

グレリン受容体（GHS-R）は主に摂食統合調節部位 である視床下部・弓状核掞よび下垂体等で発現し、成 長ホルモン (GH) 分泌促進作用や摂食行動の促進、脂 肪蓄積効果等多彩なエネルギー代謝調節作用を有する 「グレリン」の機能を発揮させる重要な受容体である (Cruz と Smith 2008)。

\section{1-1 グレリンとグレリン受容体同定の経緯}

グレリン同定の経緯は「研究物語」として興味深い
(Kojima と Kangawa 2005)。Bowers ら（1980）はオピ オイドペプチド（麻酔鎮痛効果等を持つペプチド）の 誘導体の一つが、弱い成長ホルモン $(\mathrm{GH})$ 分泌促進活 性を持つことを発見した。これが GHS (growth hormone secretagogue：成長ホルモン分泌促進因子）の

連絡先 : 小松 正憲

現所属: (独) 農研究機構・畜産草地研究所

テ 305-0901 つくば市池の台 2

(email: mkomatsu@affrc.go.jp) 
最初の発見である。その後、合成に改良が加えられ、 1984 年には強力な GHS である GHRP-6 が開発された。 また、1993 年メルク社により最初の非ペプチド性 GHS である L-692,429、さらに L-163,191（MK-0677）が開 発された。これら低分子化合物 GHS は、経口投与によっ ても十分な $\mathrm{GH}$ 分泌が認められたが、副作用の問題か ら開発は中止されたものである。GHS の GH 分泌作用 機序に関する研究も進み、GHS は成長ホルモン放出ホ ルモン $(\mathrm{GHRH})$ 受容体とは別の受容体に作用して GH 分泌を促進することが明らかになった。1996 年発 現クローニング法により GHS 受容体（GHS-R：すな わちグレリン受容体）がブタ脳下垂体 mRNA からク ローニングされた。GHS-R 受容体は典型的な 7 回膜貫 通型 G タンパク質共役型受容体（GPCR）であり、下 垂体、視床下部などで発現していることが明らかに なった（Howard ら 1996）。この時点で、GHS-R は結合 するリガンドが不明のオーファンレセプターであり、 内因性リガンドの存在が確実となったことから、世界 中でこのリガンド探しの嬂烈な研究競争が開始され た。欧米の複数の研究グループはリガンド探しのター ゲットを視床下部等脳に集中し、かつ遺伝子レベルで の検討にこだわった。これに対し、視床下部を含む幅 広い臓器でかつ遺伝子レベルのみならず、タンパク質 レベルでの検索も行っていたのが日本の “児島・寒川 ら”のグループである。彼らは、この GHS-Rのリガ ンドをラットの胃のペプチド抽出物から、世界に先駆 け、発見・同定し、グレリン (Ghrelin) と命名した (Kojima ら 1999)。また、彼らは28個のアミノ酸からなる機能 をもったグレリンの 3 番目のアミノ酸セリンが脂肪酸 のn-オクタン酸で修飾され、この修飾がグレリンの機 能発現に重要であることも明らかにした。このグレリ ン同定をめぐる研究競争をみると、多角的な観点から の研究がいかに重要であるか理解できる。Ghrelin には 成長 (Grow) と “GH” 分泌促進 (release) の意味が 込められており、この名前には研究グループ“览島・ 寒川ら”の情熱が同時に込められている（Kojimaら 1999)。

\section{$1-2$ グレリン}

グレリンのアミノ酸残基数はヒト、マウス、ブタで は 28 残基、ウシ、ヒッジで 27 残基、ニワトリで 26 残基であり、 $\mathrm{N}$ 末端の活性に必要な部分のアミノ酸配 列が非常によく保存されている。グレリンの $\mathrm{N}$ 末端か ら 3 番目のセリン残基は脂肪酸のオクタン酸でアシル 化修飾され、この修飾基がグレリンの活性に必要であ
る。このような脂肪酸で修飾された生理活性物質はグ レリン以外にない。ウシ、ヒッジのグレリンはヒト . マウス・ブタ型グレリンの 14 番目のグルタミン $(\mathrm{Gln})$ が欠如した「des-Gln14 グレリン」(27 残基型) である。 このグレリンはオクタン酸の修飾を受けており、生理 活性の種類・強さはヒト・マウス・ブタ型グレリン $(28$ 残基型）と同じである。なお、ラットの胃にも desGln14 グレリンが通常タイプのグレリンの約 $1 / 4$ 程度 存在している。グレリンは哺乳類だけでなく脊椎動物 全般に存在しており、どの動物種でも胃（あるいは相 当器官）で産生され、活性型は中鎖脂肪酸で修飾され ている。中鎖脂肪酸の修飾は脂肪酸付加酵素によって 行われる。脂肪酸修飾を受けていないグレリンの分子 型、「デスアシルグレリン」は GHS-R（以後グレリン 受容体とする）には結合せず、 $\mathrm{GH}$ 分泌促進作用はない。 デスアシルグレリンは胃や血中に多く存在し、ウシで は活性型グレリンの 7 倍程度多く存在する。デスアシ ルグレリンの特異的な受容体の存在は確定していない が、デスアシルグレリンには視床下部外側野の摂食中 枢にあるオレキシンニューロンを活性化して摂食光進 作用があるとの報告がある（Kojima と Kangawa 2005）。

\section{1-3 グレリン受容体}

グレリン受容体遺伝子は二つのエキソンからなり、 第 1 エキソンは第 1 から第 5 までの膜貫通領域、第 2 エキソンは第 6 から第 7 までの膜貫通領域をコードし ている。また、グレリン受容体遺伝子からは、premRNA が「スプライシングする」または「スプライシ ングしない」ことにより、1a 型 $(G H S-R 1 a)$ と $1 \mathrm{~b}$ 型 （GHS-R1b）の二つの mRNA が生じる。GHS-R1a 型の グレリン受容体は 7 回膜貫通型の GPCR（366 個アミ ノ酸）としてグレリンと結合し、その生理機能を発揮 する。GHS-R1b 型のグレリン受容体は 5 回膜貫通型 (ウ シでは 316 個アミノ酸) となり、グレリン結合能はない。 しかし、GHS-R1b 型のグレリン受容体は GHS-R1a 型 グレリン受容体とヘテロダイマーを形成し、GHS-R1a 型グレリン受容体の発現を調節すると考えられている (Leung P-K ら 2007)。グレリン受容体はロドプシンスー パーファミリーに属し、アミノ酸レベルでモチリン受 容体（52\% 同一性）やニューロテンシン受容体（59\% 同一性）などに配列の同一性が認められる。これら受 容体の内因性リガンドは消化管運動を制御する等多彩 な生理作用発現に関与する。 


\section{1-4 グレリンーグレリン受容体の生理作用}

グレリンーグレリン受容体には主要な生理作用とし て（1）下垂体における GH 分泌促進作用と、（2）視床 下部摂食調節領域に作用して摂食活動を高める作用 （摂食促進作用）の二つがある。

(1) GH 分泌促進作用

下垂体における $\mathrm{GH}$ の合成と分泌の調節は多くの要 因によって調節されているが、 $\mathrm{GH}$ 分泌は、基本的には、 視床下部一脳下垂体軸における (1) GHRH と GHRH 受 容体、(2)グレリンとグレリン受容体、(3)ソマトスタチ ンとソマトスタチン受容体の三つのリガンド - リガン ド受容体軸によって調節されている。GHの合成と分 泌機能に関しては、GHRH/GHRH 受容体は GH 合成が 主で $\mathrm{GH}$ 分泌が従、グレリン/グレリン受容体は $\mathrm{GH}$ 分泌が主で $\mathrm{GH}$ 合成が従、ソマトスタチン/ソマトス タチン受容体は $\mathrm{GH}$ 分泌の阻止と整理される（Lin-Su と Wajnrajch 2002）。胃（反颎動物では第 4 胃）のX/A様細胞で合成分泌されたグレリンは、近傍のグレリン 受容体を発現している求心性迷走神経を刺激し、GH 分泌を刺激する（Nonogai 2008）。視床下部弓状核グレ リンニューロンで産生されたグレリンも GHRH ニュー ロン上で発現している GHS-R1aに結合して GHRHを 放出させ、GHRH は下垂体門脈を経由して脳下垂体前 葉の GHRH 受容体を発現した GH 産生分泌細胞を刺激 し GH を分泌させる。ウシでは、視床下部の GHS-R1a のほとんどが弓状核でのみ発現し、GHS-R1aを発現す る GHRH ニューロンにグレリンが結合することによ り、 $\mathrm{GH}$ 分泌の刺激となる（Leshin ら 1994）。

\section{（2）摂食促進作用}

視床下部弓状核グレリンニューロンは、同じ弓状核 で GHS-R1aを発現する neuropeptide Y (NPY) /agoutirelated protein (AgRP) ニューロンに投射し、捸食促進 ペプチドである NPY と ArRPを分泌させる。さらに このグレリンニューロンは同様に弓状核で GHS-R1aを 発現する proopiomelanocortin (POMC) ニューロンに投 射し、摂食抑制ペプチドである $a$-melanocyte stimulating hormone ( $a-\mathrm{MSH})$ などの POMC 関連ぺプ チドの分泌を抑制して摂食促進作用を推進する (Lin-Su と Wajnrajch 2002)。また、弓状核グレリンニューロン は視床下部外側野で GHS-R1a を発現するオレキシン ニューロンに投射し、摂食促進ペプチドであるオレキ シンの分泌を促進する。さらにラットでは、弓状核の NPY と GHRH 両ニューロンにおけるNPY と GHRH 発 現上昇は GHS-R1aの発現上昇と関連すると報告されて
いる（Mano-Otagiri ら 2006）。

\section{2. ウシ・グレリン受容体遺伝子の塩基多型、分子進 化およびその塩基多型と産肉形質との関連性}

\section{2-1 研究開始の経緯}

現在までヒトでは、本遺伝子の多型と肥満、低身長、 増体との関連性が報告されてきている（Wang ら 2004 ; Baessler ら 2005)。また、弓状核特異的 GHS-R1a 発現 抑制ラットでは、体重・体長減少と摂食量減少が認め られる（Shutoら 2003）。しかしながら、ウシにおける グレリン受容体遺伝子とその多型に関する研究は 2009 年に2 報の研究報告がなされるまで皆無であった (Colinet ら 2009 ; Zhang ら 2009)。我々は、1997年か ら 2003 年まで (独) 農研機構・近畿中国四国農業研 究センター・大田研究拠点で行った黒毛和種半きょう たい家系を用いた体重・体型形質の QTL 連鎖解析研究 から、これら QTL の一つを染色体第 1 番の約 90 ～ 120 センチモルガン付近にマップし、ヒト - ウシ比較 地図からその候補遺伝子としてグレリン受容体遺伝子 を推定した（Malau-Aduliら 2005a；Malau-Aduli ら 2005b)。次に、形質に影響を与えている真の塩基変異 （QTN：Quantitative Trait Nucleotide）はグレリン受容体 遺伝子のどこなのかを明らかにしたいと考えた。2003 年当時、ウシ・グレリン受容体遺伝子全長の塩基多様 性に関する研究報告は皆無であったため、同時期に進 展していたウシ・ドラフトシークエンスデータの蓄積 (2005 年 8 月第 2 版ウシホールゲノムショットガンシー クエンスの公表）とヒトゲノムドラフトシークエンス を参考にして、ウシ・グレリン受容体遺伝子の全長に わたる塩基レベルでの变異を明らかにする研究を開始 した。本遺伝子の塩基変異の全容を明らかにするため、 DNA サンプルとして、黒毛和種、褐毛和種および日本 短角種の和牛 3 品種、および和牛の祖先型牛と考えら れる「見島牛」、和牛品種成立に関与したとされるヨー ロッパ系品種、我々のグループがフィリピン大学との 共同研究で所有しているBos indicus 系牛のフィリピン 在来牛とアメリカンーブラーマン交雑種を用いた。

\section{2-2 グレリン受容体遺伝子 5'UTR に存在するマ イクロサテライト $\left((\mathrm{TG})_{\mathrm{n}}\right)$ の多型解析と反復配列の 特徵}

\section{2-2-1 目的}

遺伝子塩基多型の全貌を明らかにするためには、で 
きるだけ少数個体で効率的に塩基多型を把握する必要 がある。第 1 版のウシドラフトシークエンスを検討す ると、未だ塩基配列が確定していない部分があったが、 グレリン受容体遺伝子 5'UTR 領域と推定できる領域内 には $(\mathrm{TG})_{\mathrm{n}}$ 型のマイクロサテライトが存在していた。 しかも興味深いことに、ヒト、マウスやラットの 5'UTR 領域内には、このようなマイクロサテライトは 存在しない。このマイクロサテライト $\left((\mathrm{TG})_{\mathrm{n}}\right)$ に多 型が存在するなら、このマイクロサテライトは遺伝子 塩基多型解析用個体選抜のマーカーになると考元、ま ずこのマイクロサテライトの多型解析を行った。解析 サンプルは和牛 3 品種を含む合計 12 品種 356 頭のゲ ノム DNA を用い、シークエンサーによる PCR 増幅産 物のフラグメント解析を行った。さらに興味深いこと に、ウシドラフトシークエンス情報から、ウシ・グレ リン受容体遺伝子マイクロサテライトの TG 反復配列 中には、1箇所 TC 配列が存在していた。マイクロサ テライトの $\mathrm{TG}$ 反復配列数に多型があった場合、この 1 箇所 TC 配列の部位をマーカーにすれば、 TG 反復伸 長の方向が $5^{\prime} \rightarrow 3^{\prime}$ 方向か、あるいは $3^{\prime} \rightarrow 5^{\prime}$ 方向か明 らかにできる。そこで、マイクロサテライトのアリル・ ホモ型 7 個体（ホモ型アリル：19，21，22，23，24, 25,28）へテロ型 1 個体 (10/19) の計 10 個体の 5'UTR マイクロサテライトの塩基配列を決定し、TG 反復の増減方向を決定した。

\section{2-2-2 結果}

5'UTR マイクロサテライト $\left((\mathrm{TG})_{\mathrm{n}}\right)$ のフラグメン 卜解析から、本座位のアリル数は 13 品種で 17 種類が 認められた（表 1)。アリルの 2 塩基反復回数は、10 回から33回まで広い範囲に分布し、これらアリル頻 度には品種間差異が認められた。主要なアリル（2塩 基反復回数）は、黒毛和種では 19、23、24 の 3 種類、 日本短角種では $20 、 23 、 25 、 28$ の 4 種類、褐毛和種（熊 本系と高知系を合わせる）では21、22、23、24の 4 種類、見島牛では $24 、 25$ の 2 種類、ホルスタイン フリージャン種では 19、21、22、24の4 種類、ヨーロッ パ系牛 4 品種は 19、21、22、23の 4 種類、Bos indicus 系牛の遺伝子をもつフィリピン在来牛では $10 、 22$ の 2 種類、アメリカンーブラーマン交雑種では 22 の 1 種 類であった。アリルの種類とその頻度には和牛 3 品種 間で差異が認められた。見島牛の主要アリルであるア リル 24 は、黒毛和種と褐毛和種では最も頻度が高かっ た。フィリピン在来牛では、Bos taurus 系牛である和 牛やヨーロッパ系牛には存在しないか、あるいは存在
しても極めて低頻度の $\mathrm{TG}$ 反復数 18 以下のアリルが特 徵的に認められた（表 1)。

5'UTR マイクロサテライトのアリルの塩基配列を決 定し、極めて興味深い結果を得た（表 1 脚注)。すな わち、本マイクロサテライトの特徴的塩基配列“TC”は、 常に $3^{\prime}$ 側から 9 反復目に位置し $\left[5^{\prime}-(\mathrm{TG})_{\mathrm{n}-9} \mathrm{TC}\right.$ ( T G) $8^{-3} 3^{\prime}$ 、 TG 反復回数の増加は、 $3^{\prime} \rightarrow 5^{\prime}$ 方向であるこ とが判明した。また、mtDNA 型が明確にBos indicus タイプをもつフィリピン在来牛 (バタンガス牛) 由来 のアリル10,19 のマイクロサテライトには、この “TC” 配列は存在せず、全て TGの反復のみであった。さらに、 mtDNA 型が明確に Bos taurus タイプをもつアメリカン -ブラーマン交雑種由来アリル19 のマイクロサテラ イトは、Bos taurus 系牛と同様に“TC”配列が 3 側か ら9 反復目に位置して存在した。これらの結果から、 5'UTR マイクロサテライト $(\mathrm{TG})_{\mathrm{n}}$ アリルには、Bos taurus 系牛タイプと Bos indicus 系牛タイプの 2 つの イプが存在し、Bos taurus 系牛とBos indicus 系牛とで は異なる分子進化を遂げてきたことを伺わせる。

本遺伝子 5' フランキング領域内のマイクロサテライ 卜 $\left((\mathrm{TG})_{\mathrm{n}}\right)$ は mRNA に転写されるのか否かを明らか にするため、ウシ視床下部・弓状核の全 RNA を用い た 5'-rapid amplification of cDNA ends（RACE）による検 討を行った。その結果、5'UTR マイクロサテライト $\left((\mathrm{TG})_{\mathrm{n}}\right)$ は非スプライシング型 mRNA（1b 型；GHS$R 1 b)$ として転写されることが判明した（図 1 - (B))。 なお、スプライシング型 mRNA（1a 型；GHS-R1a）と して転写される mRNA は 7 回膜貫通型 $\mathrm{G}$ タンパク質 結合型受容体としてグレリン認識機能をもつ通常型グ レリン受容体（GHS-R1a）に翻訳される。また、非久 プライシング型の $G H S-R 1 b m R N A$ （1b 型）は、 5 回膜 貫通型受容体（GHS-R1b）に翻訳される。前述したよ うに、この GHS-R1bにはグレリン認識機能はない。 さらに、5' フランキング領域内転写因子認識部位を検 討したところ $1 \mathrm{a}$ 型 mRNA の転写開始部位のすぐ上流 に、ApoE_B1 配列 (SCCCACCTC) とAABS_CS2 配 列（GTGAAGCAA）が存在していた。ApoEタンパク 質は very low density lipoprotein の主要成分であり、リ ポタンパク質粒子の主要クラス全ての構成成分であ る。また、AABS モチーフは C/EBP $\beta$ の結合部位であり、 C/EBP $\beta$ は熱生産に関わる褐色脂肪細胞の特異的マー カー遺伝子 uncoupling protein-1 (UPC-1) の転写調節因 子である。これらの配列はヒトやマウスには存在せず ウシ特異的であることから、ウシにおけるグレリン受 容体遺伝子の発現調節は、ヒトやマウスなどの単胃動 
表 1 グレリン受容体遺伝子（GHSR1a）の 5'UTR マイクロサテライト $\left((T G)_{n}\right)$ のアリル頻度

\begin{tabular}{|c|c|c|c|c|c|c|c|c|c|c|c|c|c|c|c|}
\hline \multirow[b]{2}{*}{ 品 } & \multicolumn{15}{|c|}{ アリル } \\
\hline & $\begin{array}{c}10^{\$ t} \\
15,16,18\end{array}$ & $19^{t}$ & 20 & $21^{t}$ & $22^{+}$ & $23^{t}$ & $24^{t}$ & $25^{t}$ & 26 & 27 & $28^{t}$ & 29 & 31 & 33 & $\chi^{2 \#}$ \\
\hline 黒毛和種 & - & $0.22^{\S}$ & - & 0.01 & 0.09 & 0.24 & 0.37 & - & - & - & - & 0.04 & - & 0.04 & $a$ \\
\hline 回本短角種 & - & 0.02 & 0.20 & 0.01 & 0.11 & 0.22 & 0.06 & 0.14 & 0.03 & - & 0.20 & - & 0.01 & - & $b$ \\
\hline 褐毛和種 & - & 0.03 & 0.08 & 0.18 & 0.18 & 0.16 & 0.23 & - & 0.13 & - & - & - & - & 0.02 & $c$ \\
\hline 見島牛 & - & - & - & 0.01 & - & 0.14 & 0.35 & 0.50 & - & - & - & - & - & - & $d$ \\
\hline ホルスタインーフリージャン種 & - & 0.29 & 0.03 & 0.13 & 0.16 & 0.07 & 0.16 & 0.02 & 0.08 & - & - & - & - & 0.06 & $c e$ \\
\hline ヨーロッパ系牛4晶種『) & - & 0.17 & 0.02 & 0.25 & 0.17 & 0.18 & - & 0.05 & 0.10 & 0.02 & 0.05 & - & - & - & $e$ \\
\hline フィリピン在来牛 & 0.23 & 0.05 & - & 0.02 & 0.57 & 0.07 & - & 0.02 & 0.04 & - & - & - & - & - & $f$ \\
\hline アメリカン-ブラーマン交雑種 & 0.10 & - & - & 0.10 & 0.60 & 0.10 & - & - & 0.10 & - & - & - & - & - & - \\
\hline \multicolumn{16}{|c|}{ \$)TG反復数 ; 熊本系+高知系; "1) ジャージー種 + スイスブラウン種 + ヘレホード種 + アバディーン-アンガス種 } \\
\hline \multicolumn{16}{|c|}{$\begin{array}{l}\text { \# アリル頻度の品種間差異 (異なる符号 } \\
{ }^{\S} \text { 太字は各品種での主要アリル頻度 } \\
{ }^{\dagger} \text { 塩基配列を決定したアリル }\end{array}$} \\
\hline \multicolumn{16}{|c|}{ 各アリルの塩基配列 (塩基反復数) ( $\left.5^{\prime} \rightarrow 3^{\prime}\right)$} \\
\hline $\begin{array}{l}\text { アリル10、TG(10) } \\
\text { アリル19、TG(10)TC(1)TG(8) } \\
\text { アリル19、TG(10)TC(1)TG(8) } \\
\text { アリル19、TG(19) } \\
\text { アリル21,TG(12)TC(1)TG(8) } \\
\text { Pリル22、TG(13)TC(1)TG(8) } \\
\text { Pリル23、TG(14)TC(1)TG(8) } \\
\text { Pリル24、TG(15)TC(1)TG(8) } \\
\text { Pリル25、TG(16)TC(1)TG(8) } \\
\text { Pリル28、TG(19)TC(1)TG(8) }\end{array}$ & $\begin{array}{l}\text { フィリピン在 } \\
\text { 黒毛和種 } \\
\text { 黑毛和種: } \\
\text { フィリビン在 } \\
\text { アバーディ } \\
\text { 褐毛和種、 } \\
\text { 黒毛和種 } \\
\text { 黒毛和種 } \\
\text { 見島牛 } \\
\text { 日本短角種 }\end{array}$ & $\begin{array}{l}\text { :来牛 } \\
\text { ホルスタ } \\
\text { :来牛 } \\
\text { アンーア } \\
\text { アメカンン }\end{array}$ & $\begin{array}{l}\text { ン種 } \\
\text { ガス種、 } \\
\text { ブラー }\end{array}$ & ン交雑程 & & & & & & & & & & & \\
\hline
\end{tabular}

物とは異なり、リポタンパク質代謝とより密接に関連 していることが推察される。

\section{2-3 ウシ・グレリン受容体遺伝子塩基多型の全容 とハプロタイプ構築ならびに系統樹解析}

\section{2-3-1 目的と方法}

遺伝子全体の塩基多型全体を明らかにするため、マ イクロサテライトの $\mathrm{TG}$ 反復数の異なるアリルを持つ サンプルを選抜した。すなわちアリル・ホモ型個体 15 頭（ホモ型アリル：19，21，22，23，24，25，28）お よびへテロ型 11 頭 $(10 / 19,19 / 23,19 / 29,19 / 33$, $20 / 26,21 / 23,21 / 33,22 / 26,22 / 28,23 / 24,23 / 33)$ の 計 26 頭のゲノム DNA を用いた。品種の内訳は、黒毛 和種 8 頭、褐毛和種 5 頭（熊本系 4 頭、高知系 1 頭）、 日本短角種 1 頭、見島牛 2 頭、ホルスタインーフリー ジャン種 2 頭、ヨーロッパ系牛 4 品種（ジャージー種 1 頭、スイスブラウン種 2 頭、ヘレフォード種 1 頭、 アバディーンーアンガス種 1 頭)、アメリカンーブラー マン交雑種 1 頭、フィリピン在来種 2 品種(イロイロ牛、 バタンガス牛各 1 頭）合計 13 品種であった。本遺伝 子の 5' フランキング領域から 3' 非翻訳領域までを含む 全遺伝子領域全体約 6.5 キロ塩基対を増幅するように プライマーセットを 17 セット（各 600 塩基対程度を 増幅）を設計し、ブロック PCR 増幅を行い、Dye
Terminator 法によりダイレクトシークエンス（両鎖解 析）を行い塩基配列決定した。塩基多型を解析した 26 個体の全塩基多型とマイクロサテライト $\left((\mathrm{TG})_{\mathrm{n}}\right)$ 型 を比較しながら、本遺伝子全体にわたるハプロタイプ を推定し、さらに、HAPLOVIEWver3.31 を用いて、本 遺伝子内のハプロタイプブロックを推定した。また、 プログラム MEGA4.0を用いて近隣結合法によりハプ ロタイプの系統樹を推定した（Tamura ら 2007）。

\section{2-3-2 結果}

13 品種 26 頭シークエンス波形データから確認でき た多型塩基箇所は全体で 53 箇所内、SNPs 㧍よび塩基 の抻入 / 欠失は 51 箇所、マイクロサテライトは 2 箇所 であった（図 1 - (A), 表 2)。主要な塩基多型のア リル頻度の品種間差異について以下に概説する。なお、 表 3 ではアリル頻度はまとめて示している。各品種に おけるアリル頻度の詳細は文献（Komatsu ら 2010）を 参照されたい（表3）。

nt-7（C>A）座位：黒毛和種、見島牛ではアリル $C$ の頻度が高く、一方、日本短角種やホルスタイン種な どヨーロッパ系牛ではアリル $A$ の頻度が高い。褐毛和 種やフィリピン在来牛では両アリル頻度は同程度であ る。

$\mathrm{L} 24 \mathrm{~V}(\mathrm{nt}+70(\mathrm{C}>\mathrm{G}))$ 座位: アリル $\mathrm{G}$ はスイス ブラウン種で比較的高頻度で認められ（アリル頻度： 
0.67）、熊本系褐毛和種（同 0.10）や黒毛和種（同 0.05） では低頻度で認められた。しかし、アリル $G$ は、日本 短角種、高知系の褐毛和種、見島牛、ホルスタイン フリージャン種、アバディーンーアンガス種、ヘレ フォード種、ジャージー種、フィリピン在来牛には認 められなかった。アリル $G$ は今までのところ、スイス ブラウン種、熊本系褐毛和種や黒毛和種に限局して存 在するユニークなアリルである。

DelR242 座位:エキソン 1 領域の塩基多型DelR242 は、 翻訳開始点から $724 \sim 726$ 番目の 3 塩基 $\mathrm{AGG}$ が久失 する変異で、グレリン受容体の 7 回膜貫通型受容体の 細胞内第 3 ドメイン 4 個のアルギニンが連続する部位 (--RRRR--) の 2 番目のアルギニンが久失する。この “AGG”3 塩基欠失遺伝子であるアリル DelR242 は、 日本短角種には高頻度で認められ（アリル頻度：0.43）、 褐毛和種 (2 系統)、ヨーロッパ系品種 4 品種（アバデ イーン・アンガス種、ヘレフォード種、ジャージー種、 スイスブラウン種)、ホルスタインーフリージャン種、 フィリピン在来牛、アメリカンーブラーマン交雑種で は低頻度で認められた。しかし、黒毛和種や見島牛で はアリルDelR242 は見いだされていない。アリル DelR242 は多くの品種で認められることから、その由 来や正常アリル・ホモ型個体とアリルDelR242 ・ ホモ 型個体間で何らかの生理的な差異が認められるのか? 非常に興味がもたれる。

イントロン 1 マイクロサテライト $\left((\mathrm{GTTT})_{\mathrm{n}}\right)$ 座位: Bos taurus 系牛やBos indicus 系牛および品種を問わず、 アリル $(G T T T){ }_{5}$ が優勢であった（アリル頻度： 0.82 以上)。アリル (GTTT) ${ }_{6}$ はスイスブラウン種で比較的 高頻度で認められ（アリル頻度：0.44）、褐毛和種（両 系統)、ホルスタインーフリージャン種、黒毛和種、フィ リピン在来牛では低頻度で認められた。しかし、日本 短角種、アバディーンーアンガス種、ヘレフォード種、 ジャージー種には本アリルは認められなかった。また、 “GTTT” 反復回数が優勢夕イプより 1 回少ないアリル $(G T T T)_{4}$ がフィリピン在来牛にのみ低頻度で認められ た（アリル頻度：0.09）。さらに、“GTTT”反復回数が 優勢タイプより 3 回多いアリル $(G T T T)_{8}$ が見島牛、 黒毛和種の特異的な種雄牛系統およびジャージー種に のみ低頻度で認められた。おそらく、アリル $(G T T T)_{4}$ かアリル $(G T T T)_{8}$ へと “GTTT” の反復回数が増加す る方向に進化してきたものと推察できる。

これら塩基多型の組み合わせハプロタイプを検討し たところ、13 品種 26 頭で 19 種類のハプロタイプが構 築できた。さらに、本遺伝子全体でハプロタイプブロッ
クを検討してみると、Bos taurus 系牛ではエキソン 1 の後半部分 $(\mathrm{nt667}(\mathrm{C}>\mathrm{T}))$ からイントロン1のほ ぼ3' 末端部位（nt2991（G＞A））までの約 2.3 キロ塩 基対のハプロタイプブロックが確認できた（図 1 (A))。このハプロタイプブロック中の塩基の多様性を 検討したところ、Bos taurus 系牛では大きく 2 グルー プに大別できることが示された。これらの結果は、塩 基多型情報を用いた系統樹解析から確認できた（図 2)。 さらに、19 種類のハプロタイプの系統樹解析から、本 遺伝子は、祖先型ハプロタイプ (Hap43) から別のBos indicus 系牛夕イプのハプロタイプが派生するとともに (Hap41，42)、Bos taurus 系牛タイプのハプロタイプが 派生し、さらにこのハプロタイプは大きく 2 つの方向 に分化したと推察できた（グループ1、Hap01〜 Hap10；グループ 2、Hap21〜 Hap26）（図 2)。Bos taurus 系牛ハプロタイプとそれらの品種分布をみると、 品種を超えて最も多く共有されているハプロタイプは Hap07であった。見島牛のもつハプロタイプ Hap04、 Hap05 はグループ 1 に属し、特異的なサブグループを 形成した。このうちハプロタイプHap04 は黒毛和種に も認められた。グループ 2 は、アミノ酸置換を伴う特 徵的な塩基多型（L24V, D191N）をもつ Hap21、 Hap22、Hap23 が属し、黒毛和種、褐毛和種、スイス ブラウン種がこれらハプロタイプを保有していた。黒 毛和種、褐毛和種 (熊本系)、ホルスタインーフリージャ ン種、スイスブラウン種のもつハプロタイプは両グ ループに分布していたが、日本短角種、褐毛和種（高 知系)、ジャージー種のそれらはグループ1のみに属 していた。アリル DelR242を含むハプロタイプは図 2 ではHap09 と Hap10 のグループ 1 にのみ存在する結果 であるが、アリル DelR242 はフィリピン在来牛やヨー ロッパ系牛多くの品種で認められる。したがって、ア リルDelR242を含むハプロタイプは通常型アリル “ $A G G ”$ とともに、その祖先型ハプロタイプ (Hap43) とともに並行して存在していたと考えるべきだろう。

ここで想像を逞しくしてみよう。マウス・ラットの グレリン受容体は DelR242 型である。ウシでのアリル DelR242 は新しい突然変異型などではなく、むしろ逆 に 4 個アルギニンタイプを生み出した極めて古い夕イ プのアリルなのかもしれない。アリルDelR242 が種の 進化の過程で消失することなく、ウシ集団に幅広く存 在するとすれば何か理由があるはずである。「動物種 は常に飢餓の危機にさらされ続けている」と考えるな ら、グレリン受容体・De1R242 型遺伝子は飢餓にあっ て有利にはたらく遺伝子なのかもしれない。 
表 2 グレリン受容体遺伝子（GHS-R1a）の塩基多型 の全容

\begin{tabular}{|c|c|c|c|c|c|}
\hline \multirow[b]{2}{*}{ 部位 } & \multirow[b]{2}{*}{ 多型種類 } & \multicolumn{4}{|c|}{ 塩基多型の数 } \\
\hline & & $\begin{array}{l}\text { インド系 } \\
\text { 牛のみ }\end{array}$ & $\begin{array}{l}\text { ヨーロパ系 } \\
\text { 牛と系牛 }\end{array}$ & $\begin{array}{l}\text { ヨーロッパ } \\
\text { 系牛のみ }\end{array}$ & 小計 \\
\hline $\begin{array}{c}\text { 5'フランキング領 } \\
\text { 域 }+5 \text { UTRR }\end{array}$ & $\begin{array}{l}\text { SNP } \\
\text { 1塩基 揮入/欠失 }{ }^{1}\end{array}$ & $\begin{array}{l}9 \\
0\end{array}$ & $\begin{array}{l}2 \\
0\end{array}$ & $\begin{array}{l}5 \\
1\end{array}$ & $\begin{array}{c}16 \\
1\end{array}$ \\
\hline エキソン 1 & $\begin{array}{l}S{ }^{2} P^{2} \\
\text { 3塩基 挿入/欠失 }\end{array}$ & $\begin{array}{l}0 \\
0\end{array}$ & $\begin{array}{l}0 \\
0\end{array}$ & $\begin{array}{l}4 \\
1\end{array}$ & $\begin{array}{l}4 \\
1\end{array}$ \\
\hline イントロン 1 & $\begin{array}{l}\text { SNP } \\
\text { 1塩基 㨂入/欠失 } \\
\text { 3塩基 挿入/久失 }\end{array}$ & $\begin{array}{c}10 \\
0 \\
1\end{array}$ & $\begin{array}{l}7 \\
1 \\
0\end{array}$ & $\begin{array}{l}6 \\
0 \\
0\end{array}$ & $\begin{array}{c}23 \\
1 \\
1\end{array}$ \\
\hline エキソン 2 & SNP & 1 & 0 & 0 & 1 \\
\hline 3'UTR & SNP & 2 & 1 & 0 & 3 \\
\hline & 合計" & 23 & 11 & 17 & 51 \\
\hline 5'UTR & $\begin{array}{c}\text { マイクロサテライト } \\
\text { (TG) }\end{array}$ & $\begin{array}{c}(5) \\
(10-18)\end{array}$ & $\begin{array}{c}(8) \\
(19-26)\end{array}$ & $\begin{array}{c}(3) \\
(27-33)\end{array}$ & $\begin{array}{c}(17)^{6} \\
(10-33)^{\prime}\end{array}$ \\
\hline イントロン 1 & $\begin{array}{c}\text { マイクロサテライト } \\
(\text { GTTT) }\end{array}$ & $\begin{array}{l}\text { (1) } \\
\text { (4) }\end{array}$ & $\begin{array}{l}(2) \\
(5,6)\end{array}$ & $\begin{array}{l}(1) \\
(8)\end{array}$ & $\begin{array}{c}(4)^{6} \\
(4,5,6,8)^{8}\end{array}$ \\
\hline
\end{tabular}

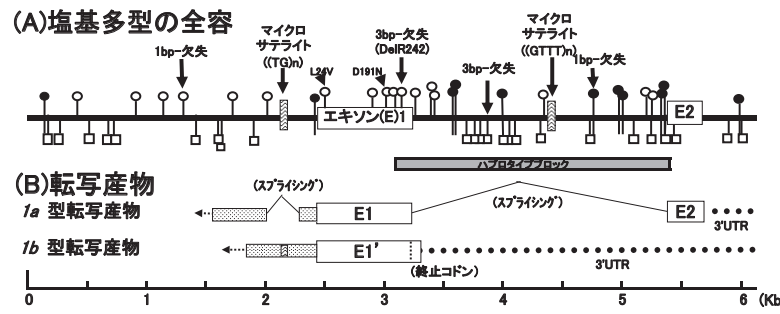

図 1 ウシ・グレリン受容体遺伝子の塩基多型の全容 と転写産物

：ヨーロッパ系牛にだけみられる塩基多型；

$\square$ : インド系牛にだけみられる塩基多型；

：両系統牛にみられる塩基多型

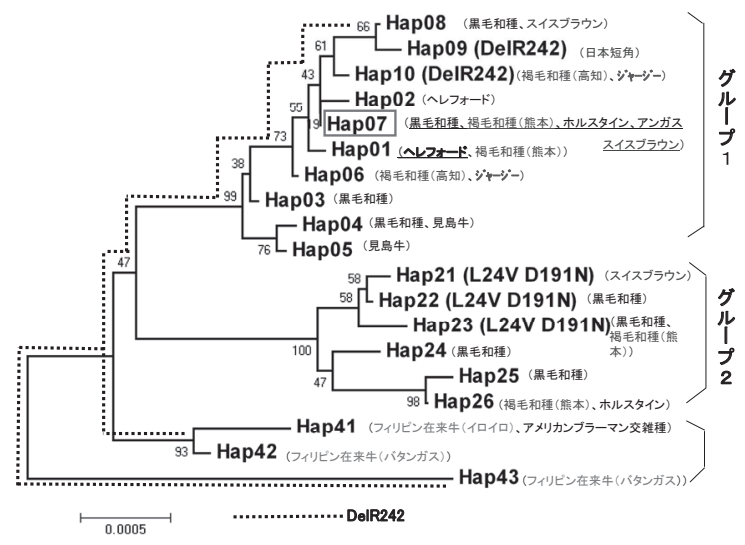

図 2 ウシ・グレリン受容体遺伝子ハプロタイプの系 統樹 数值は bootstrap 值

表 3 和牛、ヨーロッパ系牛およびフィリピン在来牛における nt-7（C>A)，L24V，DelR242 とマイクロサテライ 卜 $\left((\text { GTTT })_{\mathbf{n}}\right)$ 座位の各アリル頻度

\begin{tabular}{|c|c|c|c|c|c|c|c|c|c|c|c|}
\hline \multirow{2}{*}{ 品種 } & \multirow{2}{*}{ 頭数 } & \multicolumn{2}{|c|}{$\mathrm{nt}-7(\mathrm{C}>\mathrm{A})$} & \multicolumn{2}{|c|}{$\begin{array}{c}\mathrm{L} 24 \mathrm{~V} \\
(\mathrm{nt}+70(\mathrm{C}>\mathrm{G})) \\
\end{array}$} & \multicolumn{2}{|c|}{$\begin{array}{c}\text { DelR242 } \\
\text { (3-bp deletion) }\end{array}$} & \multicolumn{4}{|c|}{$\begin{array}{c}\text { マイクロサテライト } \\
\left((\mathrm{GTTT})_{n}\right)\end{array}$} \\
\hline & & $A$ & $c$ & $c$ & $G$ & $A G G$ & DelR242 & $(G T T T)_{4}$ & $(G T T T)_{5}$ & $(G T T T)_{6}$ & $(G T T T)_{8}$ \\
\hline 黒毛和種 & 93 & 0.34 & 0.66 & 0.995 & 0.005 & 1.00 & - & - & 0.93 & 0.07 & - \\
\hline 目本短角種 & 77 & 0.71 & 0.29 & 1.00 & - & 0.57 & 0.43 & - & 1.00 & - & - \\
\hline 褐毛和種 ${ }^{£)}$ & 31 & 0.47 & 0.53 & 0.93 & 0.07 & 0.79 & 0.21 & - & 0.82 & 0.18 & - \\
\hline 見島牛 & 58 & 0.04 & 0.96 & 1.00 & - & 1.00 & - & - & 0.99 & - & 0.01 \\
\hline ホルスタイン種 & 34 & 0.88 & 0.12 & 1.00 & - & 0.91 & 0.09 & - & 0.93 & 0.07 & - \\
\hline ヨ一ロッパ系牛4唱種】) & 30 & 0.78 & 0.22 & 0.87 & 0.13 & 0.77 & 0.23 & - & 0.83 & 0.13 & 0.03 \\
\hline フィリピン在来牛 & 28 & 0.55 & 0.45 & 1.00 & - & 0.98 & 0.02 & 0.09 & 0.86 & 0.055 & - \\
\hline
\end{tabular}

£熊本系十高知系; 『ジャージー種 +スイスブラウン種 +ヘレホード種 +アバディーン-アンガス種

\section{2-4 黒毛和種におけるグレリン受容体遺伝子の変 異と枝肉重量との関連性}

\section{2-4-1 目的と方法}

グレリン受容体遺伝子の塩基変異が黒毛和種の産肉 形質に影響を与えるか否かを明らかにするため、家畜 改良事業団プロジェクト黒毛和種後代検定牛 1,285 頭
（種雄牛 117 頭）を用いて、グレリン受容体遺伝子の塩 基多型と黒毛和種産肉形質を統計遺伝学的に解析し た。解析した塩基多型は、本遺伝子内のハプロタイプ ブロックを参考にし、(1) 5'UTR に存在するマイクロサ

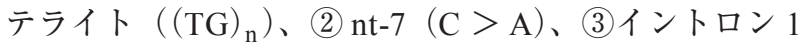
に存在するマイクロサテライト $\left((\mathrm{GTTT})_{\mathrm{n}}\right)$ を解析し た。統計解析を行った産肉形質は、と殺時体重 (WS)、 
枝肉重量 $(\mathrm{CW})$ 、平均 1 日増体重 $(\mathrm{ADG}) 、$ 、ース芯 面積 (REA)、バラ厚 (RT)、歩留基準值（YE）、皮下 脂肪厚 (SFT)、筋間脂肪厚 (IFT)、脂肪交雑 (BMS) であった。検定方法は、生後 7〜8 ケ月歯令で後代検定 去勢牛を 2 群に分け、各検定場で 20 日の予備飼育の後、 52 週間（364 日間）規定の飼料と飼養条件で飼養した ものである。

統計解析モデルは、以下の線形アニマルモデルを用 いた。

$\mathrm{y}=\mathrm{X}_{1} \mathrm{~b}+\mathrm{X}_{2} \mathrm{~g}+\mathrm{Zu}+\mathrm{e}$

$\mathrm{y}$ : 表現型值のベクター

$\mathrm{b}$ ：生年月、出生地、検定場所、検定開始年齢等の母 数効果ベクター

$\mathrm{g}$ ：グレリン受容体遺伝子の塩基多型の遺伝子の相加 的効果のベクター

$\mathrm{u}$ ：形質に関与するポリジーンのランダムな相加的効 果のベクター $\mathrm{e}$ : 残差のベクター

$\mathrm{X}_{1}, \mathrm{X}_{2}, \mathrm{Z}$ : 関連マトリックス

\section{2-4-2 結果}

グレリン受容体遺伝子の塩基多型の中で、マイナー アリル頻度が 0.10 以上で統計解析が行えるのは、 5'UTR マイクロサテライト $\left((\mathrm{TG})_{\mathrm{n}}\right)$ と nt-7 (C > A ) の 2 座位であった。5'UTR マイクロサテライト $\left((\mathrm{TG})_{\mathrm{n}}\right)$ と nt-7（C>A）の 2 座位における塩基多型と枝肉重 量との関連性を統計的に検討すると、5'UTR マイクロ サテライト $\left((\mathrm{TG})_{\mathrm{n}}\right)$ と nt-7（C>A）座位に共に統 計的にきわめて高い有意差を認め、5'UTR マイクロサ テライト $\left((\mathrm{TG})_{\mathrm{n}}\right)$ 座位での有意水準が高かった（各 $P<0.0007 、 P<0.002)$ 。なお、他に有意差を認めた 産肉形質は、と殺時時体重 (WS)、平均 1 日増体重 (ADG) の増体形質であり、脂肪交雑 (BMS) や筋間脂肪厚 (IFT) 等との間には有意な関連性は認めなかった。5'UTR マ イクロサテライト $\left((\mathrm{TG})_{\mathrm{n}}\right)$ のアリルの中で、アリル [19-TG] が増体形質に最も大きな好ましい相加的効果 を持つと推定された。後代検定の飼養条件下で、アリ ル [19-TG] は枝肉重量を約 $6.5 \mathrm{~kg}$ 増加させる相加的効 果をもつ。また、nt-7（C>A）座位では、アリル $A$ が同様に枝肉重量 (CW) 等増体形質に増加の相加的 効果を認めた（表 4 ; Komatsu 2011）。

さらに、2 座位間のアリルの組み合わせであるハプ ロタイプを検討し、11 種類のハプロタイプを推定した。 このうちハプロタイプ頻度が 0.1 以上のものは、
[19-TG] - [A]（5'UTR マイクロサテライト $\left((\mathrm{TG})_{\mathrm{n}}\right)$ と nt-7 (C > A ) のアリルの組み合わせ $) 、[22-T G]-[A]$, $[23-T G]-[C],[24-T G]-[C]$ の 4 種類であった。 なお、ハプロタイプ頻度が 0.1 以下のマイナーなハプ ロタイプとして、[15-TG]-[A], [21-TG]-[A], [22-TG] - $[C],[24-T G]$ - $[A],[26-T G]$ - $[A],[29-T G]$ - $[A]$, [33-TG]- $[C]$ の 7 種類を認めた。ハプロタイプで統 計解析をしてみると、 $[19-T G]-[A]$ タイプが最も枝 肉重量に大きな効果（平均值から約 $15 \mathrm{~kg}$ 増加）をも つことがわかった $(P<1.0 \mathrm{E}-5)$ 。なお、 $[19-T G$ 以外 $]$ - [A] タイプホモ型は最も枝肉重量が低い結果（平均 值から約 $12 \mathrm{~kg}$ 減少）となった（表 4)。これらの結果 から、5'UTR マイクロサテライト座位のアリル [19-TG] は、黒毛和種集団ではその頻度が 0.15 程度とまだ低く、 枝肉重量を増体させる有効な DNA マーカーとして活 用できることが明らかになった。

以上、グレリン受容体遺伝子 5'UTR マイクロサテラ イト $\left((\mathrm{TG})_{\mathrm{n}}\right)$ と $\left.\mathrm{nt}-7 （ \mathrm{C}>\mathrm{A}\right)$ 座位の産肉形質に及 ぼす効果を検討し、両遺伝子座は枝肉重量（CW）や 平均 1 日増体重 $(\mathrm{ADG})$ 等産肉形質に有意な影響を及 ぼし、特に5'UTR マイクロサテライト $\left((\mathrm{TG})_{\mathrm{n}}\right)$ 座位 がnt-7（C＞A）座位よりも強い影響を与えていた。 さらに、5'UTR マイクロサテライト $\left((\mathrm{TG})_{\mathrm{n}}\right)$ 座位の

表4 GHSRla 5'UTR マイクロサテライト、nt-7 (C>A）遺伝子型およびハプロタイプ型と产肉 形質との関連性

\begin{tabular}{|c|c|c|c|c|}
\hline $\begin{array}{c}\text { 遺伝子型/ハプロタイプ型 } \\
\text { およぴアリルプロタイプ頻度 }\end{array}$ & 頭数 & $\begin{array}{c}\text { と殺時 } \\
\text { 体重 } \\
\text { (kg) }\end{array}$ & $\begin{array}{c}\text { 枝肉重量 } \\
(\mathrm{kg})\end{array}$ & $\begin{array}{l}\mathrm{ADG} \\
(\mathrm{kg})\end{array}$ \\
\hline \multicolumn{5}{|l|}{ （1）5'UTR マイクロサテライト座位 } \\
\hline $19-T G / 19-T G$ & 24 & $614^{\mathrm{d}}$ & $366^{\mathrm{d}}$ & $0.96^{\mathrm{b}}$ \\
\hline 19-TG / non-19-TG ${ }^{\dagger}$ & 323 & $605^{a}$ & $361^{a}$ & $0.94^{\mathrm{a}}$ \\
\hline non-19-TG / non-19-TG & 935 & $589^{\circ}$ & $349^{\mathrm{c}}$ & $0.90^{\mathrm{C}}$ \\
\hline \multirow{2}{*}{ 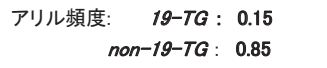 } & $\alpha^{\Uparrow}$ & 10.7 & 6.5 & 0.022 \\
\hline & SE & 3.2 & 2.0 & 0.006 \\
\hline (a,c: $P<0.0001 ;$ b,c: $P<0.05 ; \mathrm{c}, \mathrm{d}: P<0.10$ & $P$ 値 & $<0.0004$ & $<0.0007$ & $<0.0002$ \\
\hline \multicolumn{5}{|l|}{ (2) $n t-7(C>A)$ 座位 } \\
\hline$A A$ & 174 & $599^{\mathrm{a}}$ & $355^{\mathrm{a}}$ & $0.92^{\mathrm{d}}$ \\
\hline$A C$ & 609 & $598^{\mathrm{ac}}$ & $355^{\mathrm{ac}}$ & $0.91^{\mathrm{df}}$ \\
\hline$C C$ & 502 & $586^{b}$ & $348^{b}$ & $0.90^{\mathrm{e}}$ \\
\hline \multirow[t]{2}{*}{ アリル頻度: } & $P$ 值 & $<0.001$ & $<0.002$ & $<0.02$ \\
\hline & (a,c: $P<0.05$; & b,c: $P<0.005$ & d,e: $P<0.10$; e & f: $P<0.10)$ \\
\hline \multicolumn{2}{|l|}{ (3) ハプロタイプ型 } & \multicolumn{3}{|c|}{ (平均値からの差異) } \\
\hline $19-T G-A / \overline{19-T G}-A$ & 24 & +21 & +15 & +0.05 \\
\hline $19-T G-A /$ non $19-T G-A$ & 96 & +16 & +9 & +0.03 \\
\hline $19-T G-A / \operatorname{non} 19-T G-C$ & 228 & +11 & +8 & +0.03 \\
\hline non $19-T G-A /$ non 19-TG-A & 54 & -18 & -12 & -0.03 \\
\hline non19-TG-A / non19-TG-C & 381 & +1 & 0 & 0.00 \\
\hline non $19-T G-C /$ non $19-T G-C$ & 502 & -7 & -4 & -0.01 \\
\hline 全平均值 $(S D)$ & $1285^{\AA}$ & $\begin{array}{l}593 \\
(57)\end{array}$ & $\begin{array}{l}352 \\
(37)\end{array}$ & $\begin{array}{l}0.91 \\
(0.11)\end{array}$ \\
\hline ハプロタイプ頻度: & $P$ 值 & $<1.0 \mathrm{E}-5$ & $<1.0 \mathrm{E}-5$ & $<5.0 \mathrm{E}-5$ \\
\hline \multicolumn{5}{|c|}{$[19-T G]-A: 0.145 ;[19-T G]-C:-;[$ non-19-TG]-A: 0.227; [non-19-TG]-C: 0.628} \\
\hline
\end{tabular}


アリル [19-TG] が増体形質に最も大きな好ましい相 加的効果を持ち、後代検定の飼養条件下で、アリル [19-TG]は枝肉重量に対し約 $6.5 \mathrm{~kg}$ 増加させる相加的 効果をもつことが明らかとなった。このアリルの相加 的効果は、概ね体重を約 $2 \%$ 程度上昇させる効果であ る。

\section{2-5 5'UTR マイクロサテライト $\left((\mathrm{TG})_{\mathrm{n}}\right)$ と nt-7（C > A）座位と枝肉重量との関連性を説明する "translational hypothesis"}

\section{2-5-1 目的と方法}

グレリン受容体遺伝子の 5'UTR マイクロサテライト $\left((\mathrm{TG})_{\mathrm{n}}\right)$ と nt-7 (C>A）の両座位は、増体・枝肉重 量形質に関わるQTN そのものなのか？あるいは別に、 この 5'UTR マイクロサテライト $\left((\mathrm{TG})_{\mathrm{n}}\right)$ 座の極近傍 に真の QTN があるのか? 非常に興味ある点である。 我々は、黒毛和種等 Bos taurus 系牛のグレリン受容体 遺伝子の 5' フランキンギ領域から 3 'UTR まで観察され る 30 種類の塩基多型（一塩基多型、挿入 / 欠失、マイ クロサテライト）の中から考察によって塩基多型を選 抜して統計解析を行い、5'UTR マイクロサテライト $\left((\mathrm{TG})_{\mathrm{n}}\right)$ と nt-7 (C > A ) の両座位が増体・枝肉形質 に関わる QTN 候補領域であるとの結論に達した。塩 基変異から形質発現までの基本的考え方は以下であ る。すなわち、これら QTN 領域の塩基変異が弓状核 や下垂体での機能的グレリン受容体分子 (GHS-R1a) の発現量に差異をもたらす。この GHS-R1a 分子の発現 量の差異により、視床下部での摂食量増強シグナルや 下垂体での成長ホルモン放出シグナル伝達強度に差異 が生じ、摂食量と血中成長ホルモン濃度に差異をもた らし、最終的に増体・枝肉重量に遺伝的差異がでてく る。この摂食量や増体・枝肉重量に遺伝的差異を引き 起こす QTN が、5'UTR マイクロサテライト $\left((\mathrm{TG})_{\mathrm{n}}\right)$ と nt-7（C>A）の両座位と考え、以下の 3 つの仮説、 “Transcriptional hypothesis”、“Splicing hypothesis”、及び “Translational hypothesis”について検討を行った。

\section{(1) "Transcriptional hypothesis"}

初めに、両座位の変異はGHS-R1a 遺伝子からの mRNA 転写量に差異を引き起こすと考える “transcriptional hypothesis”を検討した。既に図 1 で示 したように $G H S-R 1 a$ 遺伝子からは $1 a$ 型と $1 b$ 型の 2 種 類の mRNA が転写される（Komatsu ら 2010）。1a 型の mRNA は、約 1,000 塩基長の 5'UTR のうち、5' 末端か
ら約 600 塩基下流にある5'UTR マイクロサテライト $\left((\mathrm{TG})_{\mathrm{n}}\right)$ 部位前後を含む 256 塩基がプライスアウト、 さらにイントロン 1 がプライスアウトする mRNA であ る。一方、 $1 \mathrm{~b}$ 型の mRNA は、これらの部位をプライ スアウトしない非スプライシング型 mRNA である。こ れらの mRNA からは、それぞれ(1) 7 回膜貫通型 G 夕 ンパク質共役型受容体（GPCR）であるグレリンを認 識できる機能的受容体（GHS-R1a）、(2) 5 回膜貫通型で グレリンを認識できないが GHS-R1a とへテロダイマー を形成して GHS-R1aの細胞表面での発現量を調節する dominant negative 型の受容体 (GHS-R1b) が翻訳される。 両座位の変異が、GHS-R1a 遺伝子からの $1 a$ 型の mRNA 転写量に変異を引き起こすとするなら、同時に $1 b$ 型の mRNA 転写量にも変異を引き起こし、これら 2 種類の mRNA 発現量間には正の相関があると考えるの が妥当である。とするなら、上述した GHS-R1b 受容 体の機能を考えると、両座位の変異が、GHS-R1a 分子 の発現量に直接差異をもたらすとは考えにくい。

\section{(2) "Splicing hypothesis"}

次に、両座位の変異が、GHS-R1a 遺伝子から転写さ れた pre-mRNA がスプライシングし、1a 型の mRNA の転写量に影響を与える “Splicing hypothesis”を検討 した。

まず、選択的スプライシングについて検討した。イ ントロンに存在するマイクロサテライト $\left((\mathrm{TG})_{\mathrm{n}}\right)$ が、 pre-mRNA の隣接エキソンの選択的スプライシングに 影響を与えることがヒト遺伝子疾患の症例で報告され ている（総説：Faustino と Cooper 2003）。そのイント ロン部位内のマイクロサテライトの pre-mRNA での位 置は、スプライシングに関与するリボ核タンパク質複 合体であるスプライソソームの U2 が認識する分岐点 配列（コンセンサス配列：YNCRAY、 $\underline{A}$ が分岐点）か ら下流の $3^{\prime}$ 末端 $\mathrm{AG}$ までの間に存在する（通常 20 50 塩基)。例えば、ヒト常染色体性劣性遺伝病である 囊胞性線維症 (Cystic fibrosis)のある症例では、塩素チャ ネルであるCFTR (cystic fibrosis trans-membrane conductance regulator) 遺伝子の pre-mRNA のエキソン 9 の skipping が、隣接するイントロン 8 の 3 ' 末端にあ るマイクロサテライト $\left((\mathrm{TG})_{\mathrm{n}}\right)$ の $\mathrm{TG}$ 反復数 $(\mathrm{n}=9$ 〜13）により影響を受け、 $\mathrm{TG}$ 反復数が多いと（n= 11 以上）エキソン 9 の skipping の割合が高くなる。す なわち、エキソン 9 が欠失した transcript の比率が、通 常スプライシング型 transcript のそれより高まることが 報告されている (Cuppens ら 1998)。イントロン内マ 
イクロサテライト $\left((\mathrm{TG})_{\mathrm{n}}\right)$ が選択的スプライシング とその比率に影響を与える現象は、全て pre-mRNA が スプライシングされて生じる複数の選択的スプライシ ングバリアント間に限られる。また、マイクロサテラ イト $\left((\mathrm{TG})_{\mathrm{n}}\right)$ により skipping など特異的な選択的ス プライシングの影響を受けるエキソンは、マイクロサ テライトが存在するイントロンの $5^{\prime}$ 側または $3^{\prime}$ 側に隣 接する 1 個のエキソンで、かつ、5'UTR 以外のエキソ ンに限られる。

一方、我々が注目するウシ GHS-R1a 遺伝子は 2 個の エキソンからなり、スプライシング型 transcript は 1 種 類しかなく $(1 \mathrm{a}$ 型 $) 、$ 選択的スプライシングバリアン トは存在しない。また、5'UTR マイクロサテライト

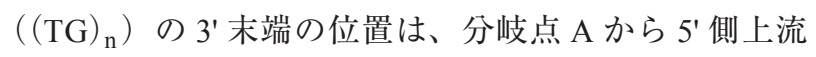
へ 46 塩基離れている。さらに、同 5 末端の位置はイ ントロンの $5^{\prime}$ 末端（GT）から下流へ113 塩基離れて いる。このように5'UTR マイクロサテライト $\left((\mathrm{TG})_{\mathrm{n}}\right)$ の位置を考えると、本マイクロサテライト $\left((\mathrm{TG})_{\mathrm{n}}\right)$ とその TG 反復数がスプライシングに影響を与えると は考えにくい。また、5'UTR マイクロサテライトが、 5'UTR イントロンとイントロン 1 の両方のスプライス アウトに影響を与えるとは更に考えにくい。

以上、スプライシングのメカニズムを考えると、 5'UTR マイクロサテライト $\left((\mathrm{TG})_{\mathrm{n}}\right)$ がグレリン受容 体の発現に影響を与える仮説として“Splicing hypothesis”は考えにくい。

\section{(3) “Translational hypothesis"}

次に、両座位の変異は、GHS-R1a 遺伝子からの各 mRNA 転写量は同じでも、各 mRNA からの翻訳量に 差異を引き起こすと考える “translational hypothesis”を 検討した。なお、mRNA からの翻訳効率は、最近のヒ トPPAR $\gamma$ mRNA の 7 種類の選択的スプライシングバ リアントの翻訳効率の比較研究を参考にした （McClelland ら 2009）（5'UTR に存在する5 個のエキソ ンの選択的スプライシングに起因するバリアントの研 究。3'UTR 側にはエキソン $1 \sim 6$ まで存在し、どの選 択的スプライシングバリアントの mRNAにも全て転写 される)。すなわち、(1) mRNAの 2 次構造の安定性が 低いほど（自由エネルギー $(\Delta \mathrm{G})$ の值が小さいほど)、 (2) 翻訳開始点付近のコンセンサス Kozac 配列（例： ACCAUGC) 中の塩基対形成数が少ないほど、(3) 5'UTR 中の翻訳開始コドン（AUG）の数が少ないほど、 (4) 5'UTR の長さが短いほど、翻訳効率は高い。したがっ て、我々の “translational hypothesis”の検討に際しは、
各ハプロタイプの mRNAの 2 次構造がもつ自由エネル ギー $(\Delta \mathrm{G})$ が最小となるように折り畳み最適 mRNA 2 次構造を推定し、その構造と翻訳量に影響を与える Kozak 配列（AGCAUGU；AUG は翻訳開始コドン）部 位における塩基対形成数を求めた。最適 mRNA 2 次構 造の推定には、ウィーン大学グループが開発したRNA fold web server である “Vienna RNA secondary structure server” (http://rna.tbi.univie.ac.at/cgi-bin/RNAfold.cgi; RNA fold web server) を用いた（Hofacker 2003）。最適 mRNA 2 次構造を推定したハプロタイプは、ハプロタ イプ頻度が 0.04 以上の 6 ハプロタイプである（1) $[19-T G]-[A]$, Hap07 ; (2) $[22-T G]-[A], \mathrm{Hap} 02$; (3) $[29-T G]-[A], \mathrm{Hap} 08$; (4) $[23-T G]-[C]$, Hap03; (5) [24-TG] - $[C]$, Hap04; (6) [33-TG] - $[C]$, Hap25)。また、GHS-R1a mRNAの全体構造として、 5'RACE 解析から、5'UTR は最も転写頻度の高い 1-2 型 とし、3'UTRはA，B，Cの三つのタイプのうち最長 のAタイプの 3'UTRをもつとした（表 5)。また、poly (A) 付加シグナル (AAUAAA) と一般的なポリ A 長 を250 個とした。nt-7（C＞A）座位のタイプは、 $A$ 夕 イプ: Hap02, 07, Hap08;Cタイプ: Hap03, Hap04, Hap25であった。GHS-R1b mRNAの全体構造は、 5'UTR は最長の主要タイプである2-1 型とし、3'UTR は三つのタイプのうち最も転写頻度が高く、かつ最短 長のC 型とした。これらの全体構造を選んだ理由は、 (1) GHS-R1a mRNA は機能をもつグレリン受容体をコー ドする mRNA として最も安定した翻訳ができると期待 できる。(2) $G H S-R 1 b$ mRNA はスプライシングが起こ らなくてもよいため5'UTR 部分および全体の mRNA は長くなり、翻訳効率はGHS-R1a mRNA より低くな ると予想できる。(3) GHS-R1b mRNA からの速やかな 翻訳による速やかな GHS-R1b 分子の合成が行われる ためには、転写頻度が高いことがGHS-R $1 b$ mRNA 翻 訳には必要と考えたからである。なお、解析の Fold algorithmsは、“minimum free energy $(\Delta \mathrm{G})$ and partition function”とし、オプションは “no GU pairs at the end of helices and no isolated base pairs”とした。 


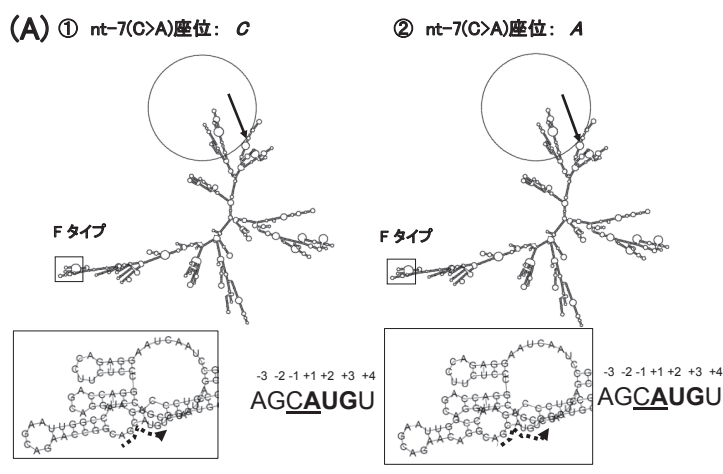

(B)
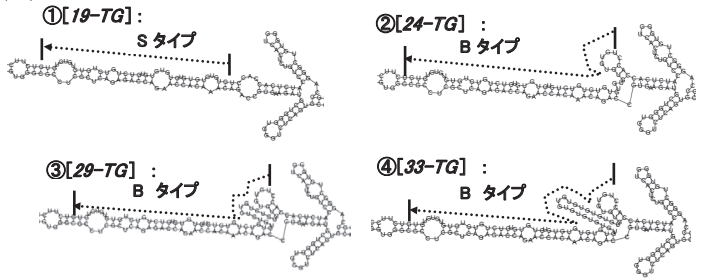

(C)

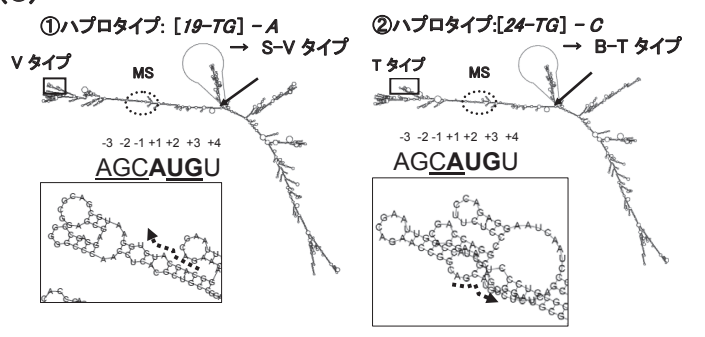

図 $31 b$ 型 mRNA および $1 a$ 型 mRNA の 2 次構造と 翻訳開始付近の配列およびタイプ

(A) $1 a$ 型 $\mathrm{mRNA}$ 全体の 2 次構造と翻訳開始点 付近の配列

*黑太字矢印は mRNAの 5' 未端; 波線矢印は Kozak 配列

(B) $1 b$ 型 mRNA の 5'UTR マイクロサテライ 卜領域の 2 次構造とタイプ

*波線矢印はマイクロサテライト部分

(C) $1 b$ 型 $\mathrm{mRNA}$ 全体の 2 次構造と翻訳開始点 付近の配列とタイプ

*黑太字矢印は mRNAの 5 ' 未端; 波線矢印は Kozak 配列

\section{2-5-2 結果}

推定した最適 mRNAの 2 次構造を図 3 - (A, B, C) に示した。GHS-R1a 折り畳み最適 mRNA 2 次構造は、 全体構造および翻訳開始点付近の構造ともに、 $A$ 夕イ プ (Hap02, 07, Hap08), Cタイプ (Hap03, Hap04, Hap25）で非常に類似していた（図 3 - (A))。また、 Kozak 配列中、塩基対結合数は、タイプおよびハプロ タイプによらず“2”で同じであった（図 3 - (A); 波線矢印の CA）。また、これら 2 次構造の自由エネル ギー $(\Delta G)$ もタイプおよびハプロタイプによらずほ ぼ同じ值であった（表 5)。なお、この mRNA 全体構
造は Foot-likeのため“F タイプ”と名付けた。したがっ て、各ハプロタイプ間にGHS-R1a mRNA の翻訳効率 に差異はないと推定できた。一方、GHS-R $1 b$ 最適 mRNA 2 次構造は、全体構造はハプロタイプによらず 類似しており、これら 2 次構造の自由エネルギー $(\Delta G)$ もタイプとハプロタイプによらずほぼ同じ值であった （表 5)。しかし、マイクロサテライト配列部位で、 [19-TG] 型と [non-19-TG] 型間で mRNA 2 次構造に 差異が認められた（図 3 - (B))。すなわち、[19-TG] 型ではストレートタイプ ( Straight； S タイプと命名) であり、[non-19-TG]型では、曲がり節様タイプ (Bending knot；B タイプと命名）であった。 $\mathrm{S}$ タイプの mRNA 2 次構造は、曲がり節様構造の B タイプの mRNAのそ れより柔軟性にそしく、翻訳関わる因子群の相互作用 が劣る “翻訳過程において negative dominant 効果”を もつと推定した。したがって、GHS-R1b mRNAの翻訳 効率は、[non-19-TG] 型> [19-TG] 型と推定した（表 6)。また、nt-7（C>A） $A$ タイプと $C$ タイプ間でも 翻訳開始点付近の構造が異なり、Kozak 配列中水素結 合塩基数は、 $A$ タイプでは“5”、Cタイプでは“2”と なり差異が認められた（図 $3-(\mathrm{C}))$ 。したがって、 $G H S-R 1 b$ mRNA の翻訳効率は、 $C$ タイプ>A タイプ と推定した（表 6)。なお、翻訳開始点付近の構造は、

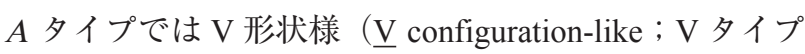
と命名)、Cタイプではトライアングル様（Triangle-like; $\mathrm{T}$ タイプと命名）であった。また、ハプロタイプ $\mathrm{B}-\mathrm{V}$ 型は、翻訳装置において [non-19-TG］部分と［nt-7（C $>\mathrm{A})$ ）の部分とが効率的に相互作用をし、相対翻訳 効率が他の三つのタイプより高くなると推定した。こ れら推定した $G H S-R 1 b$ mRNA の翻訳効率を各ハプロ タイプでまとめれば、翻訳効率の高いものから、[non19-TG]-A> [non-19-TG]-C> [19-TG]-C> [19-TG] - $A$ と推定できる（表 6）。GHS-R1b の機能は、GHSR1a とへテロダイマーを形成して GHS-R1a の細胞表面 での発現量を調節する dominant negative 効果である。 したがって、グレリン認識機能を持つ GHS-R1a 分子の 発現量は、GHS-R1b mRNA の翻訳効率の逆順、すなわ ち、 $[19-T G]-A>[19-T G]-C>[$ non-19-TG] $-C$ $>[$ non-19-TG $]-A$ と推定できる。これらの順位と統 計解析から推定したハプロタイプの体重、枝肉重量、 $\mathrm{ADG}$ 等産肉形質に及ぼす効果の順位は一致した (表4)。 以上の結果から、我々は、5'UTR マイクロサテライト $\left((\mathrm{TG})_{\mathrm{n}}\right)$ と nt-7（C>A）座位のハプロタイプと枝肉 重量との関連性を説明する仮説として、“translational hypothesis”を提案した（Komatsu ら 2011）。 
上述したように、我々は、この 5'UTR マイクロサテ ライト $\left((\mathrm{TG})_{\mathrm{n}}\right)$ と nt-7 $(\mathrm{C}>\mathrm{A})$ 座位が、産肉形質 のQTNそのものであると考えている。この仮説は今後、 in vitroの系で分子生物学的に検証する必要があるが、 検証する in vitro 実験系の構築には細心の注意を払う必 要がある。GHS-R1a と GHS-R1bを区別するモノクロー ナル抗体の準備は必須となろう。GHS-R1a 型と GHSR1b 型の mRNA に対応する配列をタンデムに配列し、 かつ同じ効率で転写される発現ベクターの構築での発 現実験など GHS-R1bの dominant negative 効果を余さず に再現できる実験系が必要である。

\section{2-6＼cjkstart黒毛和種繁殖肥育一貫経営農家における収益 上昇額の推定}

\section{2-6-1 目的と方法}

著者らが開発したプログラム（BeefIncome）（小松ら 2009）を用いて黒毛和種繁殖肥育一貫経営農家におけ る収益上昇額を推定した。推定方法を簡単に述べると、 枝肉重量を増加させる効果を持つ5'UTR マイクロサテ ライト $\left((\mathrm{TG})_{\mathrm{n}}\right)$ 座位のアリル $[19-T G]$ を 1 個持つ ことで得られる枝肉重量上昇分を $8.12 \mathrm{~kg}(=6.5 \mathrm{~kg} \times$ $440 \mathrm{~kg}$ （一般的な黒毛和種の枝肉重量） $\div 352 \mathrm{~kg}$ （後代

表 5 GHS-R $1 a$ と GHS-R $1 b$ mRNA のハプロタイプごとの 2 次構造の特徴と Koza 配列中の水素結合塩基数

\begin{tabular}{|c|c|c|c|c|c|c|c|c|c|c|c|}
\hline $\begin{array}{c}\text { mRNAの } \\
\text { スプライシ } \\
\text { ングの } \\
\text { 有無 }\end{array}$ & mRNA 型 ${ }^{\S}$ & $\begin{array}{c}\text { ハプロタイプ } \\
\text { 番号 }\end{array}$ & $\begin{array}{c}\text { mRNAの } \\
\text { 5'UTR } \\
\text { 型 }\end{array}$ & $\begin{array}{c}\text { mRNAの } \\
\text { 3'UTR } \\
\text { 型 }\end{array}$ & $\begin{array}{c}\text { poly }(A)^{+} \\
\text {付加シグ } \\
\text { ナル数 }\end{array}$ & $\begin{array}{l}\text { 5'UTR中の } \\
\text { 翻訳開始 } \\
\text { コドン } \\
\text { (AUG) 数 }\end{array}$ & $\begin{array}{c}\text { mRNAの } \\
\text { 長さ } \\
\text { (塩基) }\end{array}$ & $\begin{array}{c}\text { 5'UTRの } \\
\text { 長さ } \\
\text { (塩基) }\end{array}$ & $\begin{array}{c}\text { 5'UTR の } \\
\text { 2次構造の } \\
\text { タイプ }\end{array}$ & $\begin{array}{c}\text { 2次構造中 } \\
\text { Kozak配列 } \\
\text { 中の水素 } \\
\text { 結合塩基 } \\
\text { 数 }^{*}\end{array}$ & $\begin{array}{c}\text { 最小 } \\
\text { 自由 } \\
\text { エネルギ- } \\
(\Delta G) \\
(\mathrm{kcal} / \mathrm{mol})\end{array}$ \\
\hline \multirow{2}{*}{$\begin{array}{c}1 a \\
\text { (スプライ } \\
\text { シング型) }\end{array}$} & & & \multirow{2}{*}{$\begin{array}{l}\text { 1-2型 } \\
\text { (高転写 } \\
\text { 型) }\end{array}$} & \multirow{2}{*}{$\begin{array}{c}\text { A型 } \\
\text { (最長 } \\
\text { 3'UTR) }\end{array}$} & 1 & 5 & 2,585 & 742 & $\mathbf{F}$ & 2 & -861 \\
\hline & C & Нар03, 04, 25 & & & 1 & 5 & 2,585 & 742 & $\mathbf{F}$ & 2 & -867 \\
\hline \multirow{6}{*}{$\begin{array}{c}1 b \\
\text { (非スプラ } \\
\text { イシング } \\
\text { 型) }\end{array}$} & {$[19-T G]-A^{£}$} & Hap07 & \multirow{6}{*}{$\begin{array}{c}\text { 2-1型 } \\
\text { (最長型) }\end{array}$} & \multirow{6}{*}{$\begin{array}{c}\text { C型 } \\
\text { (最短長/ } \\
\text { 高転写 } \\
\text { 頻度) }\end{array}$} & 0 & 2 & 4,269 & 755 & $S=V$ & 5 & $-1,261$ \\
\hline & {$[22-T G]-A$} & Hap02 & & & 0 & 2 & 4,269 & 761 & $B=V$ & 5 & $-1,262$ \\
\hline & {$[29-T G]-A$} & Hap08 & & & 0 & 2 & 4,289 & 775 & $B=V$ & 5 & $-1,259$ \\
\hline & {$[23-T G]-C$} & Hap03 & & & 0 & 2 & 4,277 & 763 & $B=T$ & 2 & $-1,271$ \\
\hline & {$[24-T G]-C$} & Hap04 & & & 0 & 2 & 4,279 & 765 & $B=T$ & 2 & $-1,267$ \\
\hline & {$[33-T G]-C$} & Hap25 & & & 0 & 2 & 4,300 & 783 & $B-T$ & 2 & $-1,271$ \\
\hline
\end{tabular}

§1a : nt-7(C>A) のタイプ; $1 b:$ [5’UTR マイクロサテライト $-[\mathrm{nt}-7(\mathrm{C}>\mathrm{A})]$ ハプロタイプ

"The 3'UTR poly(A) ${ }^{+}$付加シグナル, AATAAA; poly $(A)^{+}$の長さ, 250塩基.

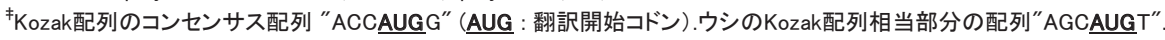

ఓ太字は主要ハプロタイプ

表 6 GHSR1a と GHSR1b mRNA の 2 次構造に基づく [5'UTR マイクロサテライト] - [nt-7 (C>A)] ハプロ夕 イプと機能的グレリン受容体レベルの関連性を説明する “translational hypothesis”

\begin{tabular}{|c|c|c|c|c|c|c|c|}
\hline $\begin{array}{c}\text { 5'UTR マイクロサテライト } \\
\text { と } \\
\text { nt-7(C>A) のタイプ }\end{array}$ & $\begin{array}{c}1 a \text { mRNA } \\
\text { の } \\
\text { 2次構造型 }\end{array}$ & $\begin{array}{c}1 a \text { mRNAの } \\
\text { 翻訳効率 }\end{array}$ & $\begin{array}{c}\text { 1a 受容体 } \\
\text { のタンパク質 } \\
\text { レベル } \\
\text { (発現量) }\end{array}$ & $\begin{array}{l}1 b \text { mRNA } \\
\text { の } \\
\text { 2次構造型 }\end{array}$ & $\begin{array}{l}1 b \text { mRNA } \\
\text { の } \\
\text { 翻訳効率 }\end{array}$ & $\begin{array}{c}1 \mathrm{~b} \text { 受容体 } \\
\text { のタンパク質 } \\
\text { レベル } \\
\text { (発現量) }\end{array}$ & $\begin{array}{c}\text { 機能的グレ } \\
\text { リン受容体 } \\
\text { レベル }\end{array}$ \\
\hline \multicolumn{8}{|l|}{ (1) 5'UTRマイクロサテライト } \\
\hline $19-T G$ & $\mathrm{~F}$ & $(+++++)^{\pi}$ & $(+++++)$ & $S$ & $(+)$ & $(+)$ & \\
\hline non-19-TG & $\mathrm{F}$ & $(+++++)$ & $(+++++)$ & B & $(+++)$ & $(+++)$ & \\
\hline \multicolumn{8}{|l|}{ (2) $n t-7(C>A)$} \\
\hline$C$ & $\mathrm{~F}$ & $(+++++)$ & $(+++++)$ & $\mathrm{T}$ & $(+++)$ & $(+++)$ & \\
\hline$A$ & $\mathrm{~F}$ & $(+++++)$ & $(+++++)$ & $\mathrm{V}$ & $(++)$ & $(++)$ & \\
\hline \multicolumn{8}{|l|}{ (3) 16 mRNAのハプロタイプ } \\
\hline$[19-T G]-C$ & $\mathrm{~F}$ & +++++ & +++++ & $S-T$ & ++ & ++ & +++ \\
\hline$[19-T G]-A$ & $\mathrm{~F}$ & +++++ & +++++ & $S=V$ & + & + & ++++ \\
\hline$[$ non-19-TG] $-C$ & $\mathrm{F}$ & +++++ & +++++ & $B=T$ & +++ & +++ & ++ \\
\hline$\left[\right.$ non-19-TG] $-A^{£}$ & $\mathrm{F}$ & +++++ & +++++ & $B=V$ & ++++ & ++++ & + \\
\hline
\end{tabular}

$\rrbracket_{+}$相対的翻訳効率; 効率レベル: +++++>++++ >+++>++ >+; ( ):各座位のみが異なる場合の推定翻訳効率

${ }^{\ddagger}$ 機能的グレリン受容体レベル $=[1 \mathrm{a}$ タンパク質レベル $]-[1 \mathrm{~b}$ タンパク質レベル $]$.

翻訳装置において[non-19-TG]部分とnt-7(C>A)部分 (B-V型)とは相互作用をし、相対翻訳効率が他の3タイプより高くなると推定。 
検定牛の平均枝肉重量))、去勢枝肉単価を「1,900 円/ $\mathrm{kg} 」$ と仮定した。農家が使用する種雄牛個体の 5'UTR マイクロサテライト型情報を得る経費 (必要経費) と して(1) DNA タイピング料金（特許使用料を含む）と (2)精液差額（農家が以前から使用していた種雄牛の精 液からアリル [19-TG] がホモ型の種雄牛精液に変更 する際の費用）と想定した。コントロール集団として、 DNA タイピングを行わない通常の集団としてハー ディーワインバーグ集団を想定した。肥育牛打よび肥 育繁殖牛 1 頭当たりの販売収益上昇額の推定は、繫殖 雌牛集団の肥育牛から得られた収益上昇総額から、 ハーディー・ワインバーグ集団の肥育牛から得られた 収益上昇総額を減じ、さらに、必要経費である(1)精液 差額の総額、(2)種雄牛または繁殖雌牛の DNA タイピ ング料金の総額を減じたものを、総販売牛頭数で除し た推定式により求めた。

\section{2-6-2 結果}

シミュレートの結果、アリル [19-TG] の頻度は黒 毛和種集団では $0.15 〜 0.20$ 程度とまだ低いため、黒 毛和種繁殖肥育一貫経営農家がアリル $[19-T G] \cdot$ ホモ 型の種雄牛の精液を交配し、子牛生産利用した場合に は、精液差額が無ければ5'UTR マイクロサテライトの タイピンル料金が 5 千円であっても、利用 3 年目から 1 頭あたり 1 万円の収益上昇が期待できることがシミュ レートできた。この結果から、グレリン受容体遺伝子 5'UTR マイクロサテライト $\left((\mathrm{TG})_{\mathrm{n}}\right)$ 座位の遺伝子型 情報は、黒毛和種においては非常に重要であり、かつ 農家レベルでも本遺伝子型情報は収益上昇に十分に利 用できると考えられた。本遺伝子型情報を農家の収益 上昇に利用するための現実的な方法としては、府県等 の公的試験研究機関が所有する基幹種雄牛あるいは販 売されている種雄牛精液について5'UTR マイクロサテ ライトとnt-7 (C>A) 遺伝子型情報を解析し、 [19-TG] - [A] ハプロタイプ・ホモ型あるいはへテロ型種雄牛 の精液を農家に提供することが考えられる。また、一 定の繁殖雌牛集団に関しても本遺伝子型を判定して、 種雄牛造成過程に本遺伝子型情報を取り入れ、積極的 にホモ型個体になるようにすることも考えられよう。 今後の他の遺伝子マーカーと合わせて農家レベルでの 経営へのグレリン受容体遺伝子型の利用が待たれる。

\section{2-7 ウシに 5'UTR マイクロサテライト ((TG $\left.)_{n}\right)$ が存在する理由と優良アリル ([19-TG]) の由来}

5'UTR マイクロサテライト $\left((\mathrm{TG})_{\mathrm{n}}\right)$ はヒトやマウ
スのゲノムには存在せず、ウシ特異的なゲノム配列で ある。ウシ、ヒトおよびマウスともに5'UTRには mRNA がスプライシングする配列領域が存在する。な ぜウシにだけ 5'UTR マイクロサテライト $\left((\mathrm{TG})_{\mathrm{n}}\right)$ 領 域が存在するのだろうか?この領域は進化の過程でヒ トやマウスゲノムからは消失してしまったのか? それ ともウシにだけ進化の過程でこの配列が挿入されたの だろうか?この疑問に対する考察として、ウシ、ヒト 拉よびマウス間で mRNA が、「GT-AGルール」でスプ ライシングする領域のゲノム配列を比較した。その結 果、ヒトやマウスでは5'UTR マイクロサテライト $\left((\mathrm{TG})_{\mathrm{n}}\right)$ 領域が進化の過程でゲノムから消失し、ウシ では維持されてきた可能性が高い。マウスでは $5^{\prime} \mathrm{UTR}$ マイクロサテライト $\left((\mathrm{TG})_{\mathrm{n}}\right)$ 領域だけに限定したゲ ノム領域の消失であり、ウシでは 5'UTR マイクロサテ ライト $\left((\mathrm{TG})_{\mathrm{n}}\right)$ は保持したものの、この配列の $3^{\prime}$ 側 下流の配列の一部を消失、ヒトではこれら領域全体を 消失したと推定できる。ウシでは長い進化の過程で維 持されてきた5'UTR マイクロサテライト $\left((\mathrm{TG})_{\mathrm{n}}\right)$ の $\mathrm{TG}$ 反復回数に高度な変異を育種過程で蓄積し、ウシ に扔ける選抜圧に柔軟に対応する遺伝的変異ソースに したと著者らは考えている。

黒毛和種における5'UTR マイクロサテライト $\left((\mathrm{TG})_{\mathrm{n}}\right)$ 座位の優良なアリル、アリル $[19-T G]$ の由来はどこ から由来したのだろうか?アリル [19-TG]は和牛の ルーッ見島牛には本アリルは認められず、また褐毛和 種、日本短角種、フィリピン在来牛では低頻度でしか 認められず、ホルスタインーフリージャン種、ヘレ フォード種、アバディーンーアンガス種では黒毛和種 程度の頻度で存在する。これらの結果を考えると、ア リル [19-TG] は黒毛和種成立に関与したホルスタイ ンーフリージャン種等ヨーロッパ系牛に由来した可能 性が高いと推察される。

\section{3. まとめ}

グレリン受容体は主に視床下部・弓状核掞よび下垂 体等で発現し、成長ホルモン $(\mathrm{GH})$ 分泌や摂食光進作 用を持つ「グレリン」の機能を発揮させる重要な受容 体である。ウシ・グレリン受容体遺伝子とその多型に 関する研究は最近までなされていなかった。我々は、 黒毛和種、褐毛和種㧍よび日本短角種の和牛 3 品種、 見島牛および和牛品種成立に関与したとされるヨー ロッパ系品種、フィリピン在来牛やアメリカンーブラー マン交雑種のBos indicus 系牛のサンプルも含めた 13 品種 26 頭のゲノム DNA を用い、5' フランキング領域 
から 3'UTR まで約 6.5 キロ塩基対のウシ・グレリン受 容体遺伝子全長にわたる塩基配列を決定し、塩基多型 の全容を明らかにした。本遺伝子全体で 53 箇所の塩 基多型を認め、うち一塩基多型（SNPs）および塩基の 挿入 / 久失は 51 箇所、マイクロサテライトは 2 箇所で あった。5'UTR に存在するマクロサテライト $\left((\mathrm{TG})_{\mathrm{n}}\right)$ の多型性は高く、ウシ 13 品種で 17 個のアリルを認め た。また、塩基多型の情報から 19 種類のハプロタイ プが推定できた。このハプロタイプから本遺伝子の分 子系統樹を作成したところ、和牛等Bos taurus 系牛で 2 系統、Bos indicus 系牛で1系統の 3 系統に大別できた。 また、見島牛には特有のハプロタイプを認めた。日本 短角種、褐毛和種、およびョーロッパ系品種でエキソ ン 1 領域に 3 塩基挿入/ 欠失の変異 DelR242 を認奴 このうち日本短角種におけるアリル DelR242 の頻度は 0.43 と高頻度であった。さらに、本遺伝子内のハプロ タイプブロックとハプロタイプの品種分布を検討し、 黒毛和種等和牛で本遺伝子の塩基多型と増体形質等と の関連解析をする際に、検討すべき塩基多型として、 5'UTR マイクロサテライト $\left((\mathrm{TG})_{\mathrm{n}}\right) 、 \mathrm{nt}-7 \quad(\mathrm{C}>\mathrm{A}) 、$ L24V $(\mathrm{nt}+70(\mathrm{C}>\mathrm{G})) 、$ DelR242 とイントロン 1 マ イクロサテライト $\left((\mathrm{GTTT})_{\mathrm{n}}\right)$ の 5 種類を選定した。 このうちイントロン 1 マイクロサテライト $\left((\mathrm{GTTT})_{\mathrm{n}}\right)$ は、Bos taurus 系牛内で、2つのハプロタイプ系統を区 別できるDNA マーカーである。

黒毛和種でグレリン受容体遺伝子の塩基レベルでの 多様性と増体能力との関連性を明らかにするため、 1,285 頭の黒毛和種後代検定牛集団を用い、本遺伝子 の上記 5 箇所の塩基多型と増体形質との関連性を検討 した。その結果、5'UTR マイクロサテライト $\left((\mathrm{TG})_{\mathrm{n}}\right)$ と nt-7 (C>A）座位が有意に増体形質と関連するこ とが判明した。また、両座位のうち、5'UTR マイクロ サテライト $\left((\mathrm{TG})_{\mathrm{n}}\right)$ 座位での有意水準が最も高かった。 関連性が認められた産肉形質は、と殺時体重 (WS)、 枝肉重量 $(\mathrm{CW})$ 、平均 1 日増体重 $(\mathrm{ADG})$ 等の増体形 質であり、脂肪交雑 (BMS) や筋間脂肪厚 (IFT) 等 との間には有意な関連性は認めなかった。5'UTR マイ クロサテライトアリル $\left((\mathrm{TG})_{\mathrm{n}}\right)$ 座位のアリルの中で、 アリル [19-TG]（TG反復 19 回）が枝肉重量を増加さ せる好ましい相加的効果を持つ。我々は、5'UTR マイ クロサテライト $\left((\mathrm{TG})_{\mathrm{n}}\right)$ と nt-7 $(\mathrm{C}>\mathrm{A})$ 座位のハ プロタイプと枝肉重量との関連性を説明する仮説とし て、“translational hypothesis”を提案する。さらに、こ の 5'UTR マイクロサテライト $\left(\left((\mathrm{TG})_{\mathrm{n}}\right)\right)$ と一塩基多 型 nt-7（C＞A）座位が QTN そのものであると考える。
黒毛和種集団に扮ける5'UTR マイクロサテライト $\left((\mathrm{TG})_{\mathrm{n}}\right)$ 座位のアリル [19-TG] の頻度は $0.15 \sim 0.20$ 程度とまだ低く、黒毛和種において枝肉重量を増体さ せる有効な DNA マーカーとして活用できる。黒毛和 種繁殖肥育一貫経営農家がアリル [19-TG]・ホモ型の 種雄牛の精液を交配し、子牛生産に利用した場合、精 液差額が無ければ、5'UTR マイクロサテライトのタイ ピング料金が 5 千円であっても、利用 3 年目から 1 頭 あたり 1 万円の収益上昇を期待できる。

\section{謝辞}

本研究は、独立行政法人農業・食品産業技術総合研 究機構- 畜産草地研究所交付金研究 (課題番号: 212-j-01-001）㧍よび独立行政法人農業生物資源研究所・ 農業生物資源ジーンバンク事業（動物遺伝資源部門） 委託研究（A. 新規特性）（平成 19 年度 $~ 21$ 年度）に より行われた。また、畜産草地研究所と（1）（社）家 畜改良事業団・家畜改良技術研究所、(2) 茨城県畜産 センター・肉用牛研究所、(3) 岩手県農業研究センター・ 畜産研究所の各研究機関との交流共同研究として行わ れた。他に多くの関倸者の協力のもとで行われた。こ こに厚く感謝申し上げる。

\section{引用文献}

Baessler A, Hasinoff MJ, Fischer M, Reinhard W, Sonnenberg GE, Olivier M, Erdmann J, Schunkert H, Doering A, Jacob HJ, Comuzzie AG, Kissebah AH, Kwitek AE. 2005. Genetic linkage and association of the growth hormone secretagogue receptor (ghrelin receptor) gene in human obesity. Diabetes, 54: 259-267.

Bowers CY, Momany F, Reynolds GA, Chang D, Hong A, Chang K. 1980. Structure-activity relationships of a synthetic pentapeptide that specifically release growth hormone in vitro. Endocrinology, 106: 663-667.

Colinet FB, Vanderick S, Charloteaux B, Eggan A, Gengler N, Renaville B, Brasseur R, Portetelle D, Renaville R. 2009. Genetic location of the bovine growth hormone secretagogue receptor (GHS-R) gene and investigation of genetic polymorphism. Animal Biotechnology, 20: 28-33.

Cruz CR, Smith RG. The growth hormone secretagogue receptor. 2008. Vitamins and Hormones, 77: 47-88.

Cuppens H, Lin W, Jaspers M, Costes B, Teng H, Vankeerberghen A, Jorissen M, Droogmans G, Reynaert I, Goossens M, Nilius B, Cassiman J-J. 1998. 
Polyvariant mutant cystic fibrosis transmembrane conductance regulator genes: the polymorphic (TG) $\mathrm{m}$ locus explains the partial penetrance of the T5 polymorphism as a disease mutation. Journal of Clinical Investigation, 101: 487-496.

Faustino NA, Cooper TA. 2003. Pre-mRNA splicing and human disease. Genes and Development, 17: 419-437.

Hofacker IL. 2003. Vienna RNA secondary structure server. Nucleic Acids Reserch, 31: 3427-3431.

Howard AD, Feighner SD, Cully DF, Arena JP, Liberator PA, Rosenblum CI, Hamelin M, Hreniuk DL, Palyha OC, Anderson J, Paress PS, Diaz C, Chou M, Liu KK, McKee KK, Pong SS, Chaung LY, Elbrecht A, Dashkevicz M, Heavens R, Rigby M, Sirinathsinghji DJ, Dean DC, Melillo DG, Patchett AA, Nargund R, Griffin PR, DeMartino JA, Gupta SK, Schaeffer JM, Smith RG, Van der Ploeg LH. 1996. A receptor in pituitary and hypothalamus that functions in growth hormone release. Science, 273: 974-977.

Kojima M, Hosoda H, Date Y, Nakazato M, Matsuo H, Kangawa K. 1999. Ghrelin is a growth-hormonereleasing acylated peptide from stomack. Nature, 402:656-660.

Kojima M, Kangawa K. 2005. Ghrelin: Structure and function. Physiological Review, 85:495-522.

小松正憲、西尾元秀、佐藤正寛、千田雅之、広岡博之. 2009. 黒毛和種繁殖肥育一貫経営農家経営における DNA マーカー情報活用による肥育牛販売収益上昇 額の推定 日本畜産学会報 80: 157-169.

Komatsu M, Fujimori Y, Sato Y, Okamura H, Sasaki S, Itoh T, Morita M, Nakamura R, Oe T, Furuta M, Yasuda J, Kojima T, Watanabe T, Hayashi T, Malau-Aduli AEO, Takahashi H. 2010. Nucleotide polymorphisms and the 5'-UTR transcriptional analysis of the bovine growth hormone secretagogue receptor 1a (GHS-R1a) gene. Animal Science Journal, 81: 530-550.

Komatsu M, Itoh T, Fujimori Y, Satoh M, Myazaki Y, Takahashi H , Shimizu K, Malau-Aduli AEO,Morita M. 2011. Genetic association of GHS-R1a 5'UTRmicrosatellite and nt-7 (C>A) loci on growth and carcass traits in Japanese Black cattle. Animal Science Journal, 82: 396-405.

Leshin LS, Barb CR, Kiser TE, Rampacek GR, Kraeling RR. 1994. Growth hormone-releasing hormone and somatostatin neurons within the porcine and bovine hypothalamus. Neuroendocrinology, 59: 251-264.

Leung P-K, Chow KBS, Lau P-N, Chu K-M, Chan C-B, Cheng CHK, Wise H. 2007. The truncated ghrelin receptor polypeptide GHS-R1b acts as a dominantnegative mutant of the ghrelin receptor. Cellular Signalling, 19: 1011-1022.

Lin-Su K, Wajnrajch MP. 2002. Growth hormone releasing hormone $(\mathrm{GHRH})$ and the GHRH receptor. Reviews in,Endocrine \& Metabolic Disorders, 3: 313-323.

Malau-Aduli AEO, Niibayashi T, Kojima T, Oshima K, Mizoguchi Y, Komatsu M. 2005a. Interval mapping of growth quantitative trait loci in Japanese Black cattle using microsatellite DNA markers and half-sib regression analysis. Animal Science Journal, 76: 11-18.

Malau-Aduli AEO, Niibayashi T, Kojima T, Oshima K, Mizoguchi Y, Komatsu M. 2005b. Mapping the quantitative trait loci (QTL) for body shape and conformation measurements on BTA1 in Japanese Black cattle. Animal Science Journal, 76: 19-27.

Mano-Otagiri A, Nemoto T, Sekino A, Yamauchi N, Shuto Y, Sugihara H, Oikawa S, Shibasaki T. 2006. Growth hormone-releasing hormone (GHRH) neurons in the arcuate nucleus (Arc) of the hypothalamus are decreased in rats whose expression of ghrelin receptor is attenuated: Evidence that ghrelin receptor is involved in the up-regulation of GHRH expression in the Arc. Endocrinology, 147: 4093-4103.

McClelland S, Shrivastava R, Medh JD. 2009. Regulation of translational efficiency by disparate 5'-UTRs of PPAR $\gamma$ splice variants, PPAR Research Article ID 193413, p.8. (doi:10.1155/2009/193413)

Nonogai K. 2008. Ghrelin and feedback systems. Vitamins and Hormones, 77: 149-170.

Shuto Y, Shibasaki T, Otagiri A, Kuriyama H, Ohata H, Tamura H, Kamegai J, Sugihara H, Oikawa S, Wakabayashi I. 2002. Hypothalamic growth hormone secretagogue receptor regulates growth hormone secretion, feeding, and adiposity Journal of Clinical Investigation, 109: 1429-1436.

Tamura K, Dudley J, Nei M, Kumar S. 2007. MEGA4: Molecular Evolutionary Genetics Analysis, MEGA Software Version 4.0 Molecular Biology and Evolution, 24: 1596-1599.

Wang HJ, Geller F, Dempfle A, Schäuble N, Friedel S, Lichtner P, Fontenla-Horro F, Wudy S, Hagemann S, 
Gortner L, Huse K, Remschmidt H, Bettecken T, Meitinger T, Schäfer H, Hebebrand J, Hinney A. 2004. Ghrelin receptor gene: identification of several sequence variants in extremely obese children and adolescents, healthy normal-weight and underweight students, and children with short normal stature. Journal of Clinical Endocrinology and Metabolism, 89: 157-162.

Zhang B, Chen H, Guo Y, Zhang L, Zhao M, Lan X, Zhang C, Pan C, Hu S, Wang J, Lei C. 2009. Associations of polymorphism within the GHS-R gene with growth traits in Nanyang cattle. Molecular Biological Reports, $36: 2259-2263$. 